\title{
PERSEPSI MASYARAKAT MENGENAI OBAT TRADISIONAL DI KELURAHAN SIMPANG BARU KECAMATAN TAMPAN KOTA PEKANBARU
}

\author{
Ratna Sari Dewi $^{1 *}$, Sri Fadilah Nur illahi ${ }^{2}$, Fina Aryani ${ }^{3}$, Erniza Pratiwi $^{4}$, Tiara Tri Agustini ${ }^{5}$ \\ ${ }^{l}$ Sekolah Tinggi Ilmu Farmasi Riau, Pekanbaru, 28928 \\ I*e-mail : ratnasaridewi@stifar-riau.ac.id
}

\begin{abstract}
ABSTRAK
Obat tradisional adalah obat yang digunakan secara empiris untuk pengobatan tradisional yang berasal dari tumbuhan, hewan, mineral, sediaan sarian (galenik), atau campuran dari bahan tersebut yang dapat dibuat menjadi bentuk sediaan yang bervariasi di antaranya adalah kapsul, tablet, pil dan lain-lain, tanpa menggunakan bahan kimia obat. Sebagian besar masyarakat masih menggunakan obat tradisional sebagai terapi. Penelitian ini bertujuan untuk mengetahui persepsi masyarakat mengenai obat tradisional di Kelurahan Simpang Baru Kecamatan Tampan Kota Pekanbaru. Penelitian ini merupakan penelitian observasional/survei yang bersifat deskriptif. Pengambilan sampel dilakukan dengan cara purposive sampling, sampel yang didapat dalam penelitian ini sebanyak 105 responden yang pernah menggunakan obat tradisional tiga bulan terakhir. Hasil penelitian menunjukkan bahwa masih baiknya persepsi masyarakat mengenai obat tradisional di Kelurahan Simpang Baru. Dari hasil ini dapat disimpulkan bahwa persepsi yang banyak timbul di masyarakat mengenai obat tradisional adalah obat tradisional buatan Indonesia kandungannya lebih aman (halal) $(87,8 \%)$ dan untuk persepsi terhadap alasan masyarakat menggunakan obat tradisional karena obat tradisional digunakan secara turuntemurun $(82,7 \%)$.
\end{abstract}

Kata kunci: Persepsi, Masyarakat, Obat Tradisional

\section{ABSTRACT}

Traditional medicine is medicine that is used empirically for traditional medical derived from plants, animals, minerals, preparations (galenic), or a mixture of these materials that can be made into various dosage forms including capsules, tablets, pills and others, without using medicinal chemicals. This study aims to determine public perceptions about traditional medicine in the Simpang Baru Village, Tampan District, Pekanbaru City. This research is an observational / survey research which is descriptive in nature. Sampling was done by purposive sampling, the sample obtained in this study were 105 respondents who had used traditional medicine the last three months. The results showed that there was still a good public perception of traditional medicine in Simpang Baru Village. From these results it can be concluded that the perceptions that arise in the community regarding traditional medicine are traditional medicines made in Indonesia, the content is safer (halal) $(87.8 \%)$ and for the perception of the reasons people use traditional medicines because traditional medicines are hereditary $(82.7 \%)$.

Keywords: Perception, Society, Traditional Medicine

\section{PENDAHULUAN}

WHO (World Health Organization) merekomendasikan penggunaan obat tradisional dalam pemeliharaan kesehatan masyarakat, pencegahan dan pengobatan penyakit, terutama untuk penyakit kronis, degenaratif dan kanker. WHO juga mendukung dalam peningkatan keamanan dan khasiat dari obat tradisional (Bustanussalam, 2016).

Pengobatan konvensional menggunakan obat kimia sintetik diyakini mahal dan dapat menurunkan kualitas hidup akibat adanya efek samping. Peningkatan penggunaan obat tradisional ini khususnya terjadi pada negara berkembang. WHO mengklaim $80 \%$ populasi di negara berkembang menggunakan obat tradisional. Meningkatnya penyakit kronis degeneratif juga menjadi faktor yang mempengaruhi penggunaan obat tradisional, karena pengobatan yang pada umumnya sangat lama, sehingga masyarakat memilih alternatif pengobatan yang lebih murah dari segi biaya dan diyakini lebih aman dari pada obat kimia (Anonim, 2013).

Masyarakat di Indonesia sudah banyak mengkonsumsi berbagai jenis obat tradisional dari ramuan sendiri bahkan ramuan jadi. Dari data BPOM (Badan Pengawas Obat dan Makanan) bahwa obat tradisional ramuan jadi yang memiliki izin edar di Indonesia sampai dengan September 2018, tercatat 2.868 produk obat tradisional dan suplemen kesehatan (Alamsyah, 2018) termasuk 18 fitofarmaka, OHT (Obat Herbal Terstandar) sebanyak 64 produk, dan untuk jamu terdaftar sebanyak 7.710 (Burhani, 2017).

Berdasarkan data RISKESDAS (Riset Kesehatan Dasar) pada tahun 2018 penduduk Indonesia melakukan pengobatan menggunakan ramuan jadi obat tradisional sebanyak (48\%) untuk pengobatan menggunakan obat tradisional ramuan sendiri $(31,8 \%)$ dan memanfaatkan YANKESTRAD (Pelayanan Kesehatan Tradisional) sebanyak $(31,4 \%)$ (Anonim, 2018).

Obat tradisional seharusnya dibuat dengan bahan alami, namun pada tahun 2008 BPOM banyak menemukan kasus terjadinya obat tradisional yang tidak memenuhi syarat kesehatan, sehingga beberapa obat tradisional seperti jamu mengandung BKO (Bahan Kimia Obat) (Jati, 2008), yang apabila dikonsumsi dalam jangka panjang bisa berbahaya bagi kesehatan dan tentunya akan mempengaruhi persepsi masyarakat dalam menggunakan obat tradisional.

Berdasarkan penelitian mengenai persepsi masyarakat pengunjung apotek di Kelurahan Muja Muju Kecamatan Umbul Harjo Kota Yogyakarta terhadap obat tradisional sebagian besar responden yaitu lebih dari $(50 \%)$ sudah baik dan benar serta ada hubungan yang signifikan antara persepsi dengan 
tingkat pendidikan (Hidayati dan Perwitasari, 2011). Penelitian yang dilakukan oleh Rahayu (2014) bahwa masyarakat memilih pengobatan tradisional disebabkan oleh berbagai faktor, dan faktor paling dominan dalam memilih pengobatan tradisional adalah kebudayaan dan pendidikan.

Penelitian selanjutnya oleh Ervina dan Ayubi (2018) di Kota Bengkulu sebanyak 64\% penderita hipertensi memiliki kepercayaan tinggi terhadap pengobatan tradisional, pengalaman keluarga dan biaya murah menjadi alasan yang paling banyak dinyatakan oleh penderita ketika memilih pengobatan tradisional.

Kelurahan Simpang Baru merupakan salah satu kelurahan yang berada di Kecamatan Tampan Kota Pekanbaru. Kelurahan Simpang Baru memiliki daerah cukup luas wilayahnya yaitu lebih kurang 23,788 km2 dengan jumlah warga 8.304 (Anonim, 2017). Penelitian sebelumnya yang telah dilakukan oleh (Novia, 2018) mengenai gambaran penggunaan obat tradisional sebagai alternatif pengobatan di Kelurahan Simpang Baru bahwa masih banyak masyarakat yang menggunakan obat tradisional salah satunya adalah jamu sebanyak (52\%), sehingga peneliti tertarik ingin mengetahui bagaimana persepsi masyarakat mengenai obat tradisional di Kelurahan Simpang Baru Kecamatan Tampan Kota Pekanbaru.

\section{METODOLOGI PENELITIAN}

Penelitian mengenai persepsi masyarakat terhadap obat tradisional ini dilakukan di kelurahan Simpang Baru kecamatan Tampan. Penelitian ini merupakan penelitian observational/survei yang bersifat deskriptif menggunakan kuesioner untuk mengetahui bagaimana persepsi masyarakat mengenai obat tradisional. Sampel yang digunakan pada penelitian ini sebanyak 105 responden untuk mewakili 35 RT.

Lembar kuesioner disusun merujuk pada kategori yang digunakan oleh Hidayati dan Perwitasari (2011), yaitu pernyataan persepsi mengenai obat tradisional dan pernyataan persepsi terhadap alasan penggunaan obat tradisional, kemudian disusun ulang sesuai dengan faktorfaktor yang mempengaruhi persepsi (Walgito, 2010) dan dilanjutkan dengan uji validitas dan reliabilitas sehingga didapatkan pernyataan yang valid untuk digunakan pada lembar kuesioner.

Pada penelitian ini dilakukan uji validitas dan reliabilitas terlebih dahulu terhadap 20 responden sehingga didapatkan pertanyaan yang valid dengan nilai $r$ hitung $\geq$ 0,444 dan alpha cronbach's yaitu 0,76.

Analisis data terhadap data sosiodemografi responden, data persepsi masyarakat mengenai obat tradisional dan data persepsi terhadap alasan menggunakan obat tradisional, untuk persepsi diperoleh dari lembar kuesioner dengan melakukan pemberian skor likert pada setiap pernyataan yang sudah memiliki kategori dengan penilaian sebagai berikut:
Tabel 1. Kategori Penilaian Skor Likert

\begin{tabular}{|c|c|}
\hline Kategori & Skor \\
\hline Sangat Setuju & 5 \\
\hline Setuju & 4 \\
\hline Cukup Setuju & 3 \\
\hline Tidak Setuju & 2 \\
\hline Sangat Tidak Setuju & 1 \\
\hline
\end{tabular}

Pada setiap pernyataan tiap kategori yang telah diberikan nilai maka masing-masingnya akan dijumlahkan dan dikalikan dengan scale rating dari skor likert, dengan rumus sebagai berikut:

$$
\text { Total }=\mathrm{T} \times \mathrm{Pn}
$$

\section{Keterangan}

$$
\text { Pn : Pilihan angka skor likert }
$$

Semua hasil yang didapatkan untuk setiap kategori akan dijumlahkan tiap pernyataan dan digunakan untuk menghitung persentase menggunakan rumus sebagai berikut:

Rumus indeks $\%=$ Total Skor $\times 100$

\section{$\mathrm{Y}$}

Keterangan:

Total skor : Total tiap kategori yang dijumlahkan untuk setiap pernyataan

$\begin{array}{llll}\text { Y } & \text { l } & \text { Skor } & \text { tertinggi } \\ & \text { likert } & \times & \text { jumlah }\end{array}$

responden

Persentase yang diperoleh akan dilihat berdasarkan kriteria yang ada pada tabel analisis interpretasi berikut ini:

Tabel 2. Kriteria Analisa Deskriptif Persentase Nilai (Febtriko dan Puspitasari, 2018)

\begin{tabular}{|c|c|}
\hline Persentase & Kriteria \\
\hline $0 \%-19,99 \%$ & $\begin{array}{c}\text { Sangat Tidak Setuju atau } \\
\text { Kurang Baik Sekali }\end{array}$ \\
\hline \hline $20 \%-39,99 \%$ & Tidak Setuju atau Kurang Baik \\
\hline $40 \%-59,99 \%$ & Cukup Setuju atau Netral \\
\hline $60 \%-79,99 \%$ & Setuju atau Baik \\
\hline $80 \%-100 \%$ & Sangat Setuju atau Sangat Baik \\
\hline
\end{tabular}




\section{HASIL DAN PEMBAHASAN}

Dari penelitian yang telah dilakukan dengan 105 responden yang menggunakan obat tradisional selama 3 bulan terakhir didapatkan hasil:

Tabel 3. Data Sosiodemografi Responden Kelurahan Simpang Baru Kecamatan Tampan

\begin{tabular}{|c|l|c|}
\hline Kategori & Keterangan & Persentase (\%) \\
\hline Jenis Kelamin & Laki - laki & 71,4 \\
\cline { 2 - 3 } & Perempuan & 28,6 \\
\hline \multirow{4}{*}{ Usia Dewasa } & Awal (18-40 tahun) & 79 \\
\cline { 2 - 3 } & $\begin{array}{l}\text { Madya (41-60 } \\
\text { tahun) }\end{array}$ & 19 \\
\cline { 2 - 3 } & $\begin{array}{l}\text { Lanjut (61 tahun ke } \\
\text { atas) }\end{array}$ & \\
\hline \multirow{4}{*}{$\begin{array}{c}\text { Tingkat } \\
\text { Pendidikan }\end{array}$} & $\begin{array}{l}\text { Rendah (tidak } \\
\text { sekolah-SD) }\end{array}$ & 9,5 \\
\cline { 2 - 3 } & Menengah (SMP- & 74,3 \\
\cline { 2 - 3 } & $\begin{array}{l}\text { Tinggi (Peguruan } \\
\text { Tinggi) }\end{array}$ & 16,2 \\
\hline $\begin{array}{c}\text { Status } \\
\text { Pekerjaan }\end{array}$ & Bekerja & 70,5 \\
\cline { 2 - 3 } & Tidak Bekerja & 29,5 \\
\hline
\end{tabular}

Dari hasil diatas dapat kita lihat bahwa yang paling banyak menggunakan obat tradisional adalah responden jenis kelamin laki- laki 71,4\%.

Berdasarkan usia responden yaitu dengan kategori dewasa awal (18-40 tahun) 79\% hal ini juga didukung dari data stastistik kantor Kelurahan Simpang Baru pada tahun 2013 bahwa berdasarkan kelompok umur dengan usia dewasa memiliki persentasi yang lebih besar dibandingkan dewasa madya dan dewasa lanjut (Anonim, 2014).

Berdasarkan tingkat pendidikan responden yaitu dengan tingkat pendidikan menengah (SMP- SMA) 74,3\% Pendidikan merupakan salah satu faktor yang berpengaruh terhadap tingkat daya tangkap informasi, sikap, pengetahuan, dan perilaku kesehatan, sehingga tingkat pendidikan responden perlu diketahui (Istaminingdyah, 2008).

Berdasarkan status pekerjaan responden yaitu bekerja $70,5 \%$ Pekerjaan juga merupakan hal yang penting dalam mempengaruhi persepsi karena dengan bekerja sesorang dapat saling berinteraksi dan bertukar pengalaman sebagai menambah wawasan termasuk dalam hal pengobatan sehingga hal ini juga mempengaruhi persepsi masyarakat dalam menggunakan obat tradisional dan meningkatkan pengetahuan terhadap obat tradisional.
Tabel 4. Skor dan Persentase (\%) Persepsi Mengenai Obat Tradisional

\begin{tabular}{|c|c|c|c|}
\hline Pernyataan & $\begin{array}{l}\text { Total } \\
\text { skor/ } \\
\text { Y }\end{array}$ & $\%$ & Interprestasi \\
\hline $\begin{array}{l}\text { Obat tradisional } \\
\text { dengan kemasan } \\
\text { mewah }\end{array}$ & $\begin{array}{l}345 / \\
525\end{array}$ & 65,7 & $\begin{array}{l}\text { Setuju } \\
\text { atau Baik }\end{array}$ \\
\hline $\begin{array}{l}\text { Dokter meresepkan } \\
\text { obat tradisional }\end{array}$ & $\begin{array}{l}396 / \\
525\end{array}$ & 75,4 & $\begin{array}{l}\text { Setuju } \\
\text { atau Baik }\end{array}$ \\
\hline $\begin{array}{l}\text { Tanaman obat } \\
\text { keluarga perlu } \\
\text { dipelihara } \\
\text { dirumah }\end{array}$ & $\begin{array}{l}455 / \\
525\end{array}$ & 86,7 & $\begin{array}{c}\text { Sangat } \\
\text { Setuju atau } \\
\text { Sangat Baik }\end{array}$ \\
\hline $\begin{array}{l}\text { Bapak/ibu/saudar a } \\
\text { sering minum jamu } \\
\text { gendong }\end{array}$ & $\begin{array}{l}333 / \\
525\end{array}$ & 63,4 & $\begin{array}{c}\text { Setuju } \\
\text { atau Baik }\end{array}$ \\
\hline $\begin{array}{l}\text { Penggunaan obat } \\
\text { tradisional } \\
\text { meningkat }\end{array}$ & $\begin{array}{l}389 / \\
525\end{array}$ & 74,1 & $\begin{array}{r}\text { Setuju } \\
\text { atau Baik }\end{array}$ \\
\hline $\begin{array}{l}\text { Obat tradisional } \\
\text { khasiatnya } \\
\text { dipercaya secara } \\
\text { turun-temurun }\end{array}$ & $\begin{array}{l}448 / \\
525\end{array}$ & 85,3 & $\begin{array}{c}\text { Sangat } \\
\text { Setuju atau } \\
\text { Sangat Baik }\end{array}$ \\
\hline $\begin{array}{l}\text { Obat tradisional } \\
\text { buatan Indonesia } \\
\text { kandungannya lebih } \\
\text { aman (halal) }\end{array}$ & $\begin{array}{l}461 / \\
525\end{array}$ & 87,8 & $\begin{array}{c}\text { Sangat } \\
\text { Setuju atau } \\
\text { Sangat Baik }\end{array}$ \\
\hline $\begin{array}{l}\text { Obat tradisional } \\
\text { kandungannya } \\
\text { jelas diketahui } \\
\text { dari pada obat } \\
\text { modern }\end{array}$ & $\begin{array}{l}413 / \\
525\end{array}$ & 78,7 & $\begin{array}{c}\text { Setuju } \\
\text { atau Baik }\end{array}$ \\
\hline
\end{tabular}

Bersadarkan data diatas persepsi yang banyak timbul pada masyarakat Kelurahan Simpang Baru Kecamatan Tampan Kota Pekanbaru mengenai obat tradisional adalah obat tradisional buatan Indonesia kandungannya lebih aman (halal) 87,8\%. Hal ini juga dapat dikaitkan dengan mayoritas yang beragama Islam. Data bahwa responden yang berada di Kelurahan Simpang Baru Kecamatan Tampan Kota Pekanbaru sebanyak $(84,25 \%)$ beragama Islam. Konsumen Islam cenderung memilih produk yang telah dinyatakan halal oleh lembaga yang berwenang dikarenakan produk yang telah dinyatakan halal lebih aman dan terhindar dari kandungan zat berbahaya (Sumarwan, 2011) dan telah dibuktikan dengan penelitian lain bahwa persepsi label halal berpengaruh signifikan terhadap keputusan pembelian (Alim, dkk. 2018). 
Pada zaman dahulu nenek moyang memiliki kemampuan menggunakan ramuan tradisional untuk mengobati keluarga sendiri. Obat tradisional seperti inilah yang akan mendasari berkembangnya pengobatan tradisional di Indonesia, sehingga cara tradisional ini dikembangkan oleh pemerintah dalam program TOGA (Tanaman Obat Keluarga). Program ini lebih mengacu pada selfcare, yaitu pencegahan dan pengobatan ringan pada keluarga (Suharmiati dan Handayani, 2006).

Berdasarkan penelitian, kategori dengan persentase tertinggi kedua mengenai persepsi masyarakat terhadap obat tradisional adalah sangat setuju (86,7\%) apabila tanaman obat keluarga perlu untuk ditanam di rumah. TOGA merupakan cara yang efektif untuk penggunaan obat tradisional secara langsung apabila dibutuhkan sehingga tanaman obat tradisional perlu ditanam di rumah. Dari hasil penelitian merdekawati (2016) bahwa masyarakat menggunakan obat tradisional untuk menyembuhkan penyakit ringan yang dideritanya dan persentase paling tinggi menunjukan bentuk sediaan yang banyak digunakan adalah rebusan tanaman obat $(65 \%)$.

Tabel 5. Skor dan Persentase (\%) Persepsi terhadap Alasan Menggunakan Obat Tradisional

\begin{tabular}{|c|c|c|c|}
\hline Pernyataan & $\begin{array}{l}\text { Total } \\
\text { skor/ } \\
\text { Y }\end{array}$ & $\%$ & Interprestasi \\
\hline $\begin{array}{l}\text { Harga obat } \\
\text { tradisional } \\
\text { lebih murah }\end{array}$ & $\begin{array}{l}395 / \\
525\end{array}$ & 75,2 & $\begin{array}{c}\text { Setuju atau } \\
\text { Baik }\end{array}$ \\
\hline $\begin{array}{l}\text { Back to nature } \\
\text { (kembali ke } \\
\text { alam) }\end{array}$ & $\begin{array}{l}401 / \\
525\end{array}$ & 76,4 & $\begin{array}{c}\text { Setuju atau } \\
\text { Baik }\end{array}$ \\
\hline $\begin{array}{l}\text { Tidak sembuh } \\
\text { dengan obat } \\
\text { modern }\end{array}$ & $\begin{array}{l}327 / \\
525\end{array}$ & 62,3 & $\begin{array}{c}\text { Setuju atau } \\
\text { Baik }\end{array}$ \\
\hline $\begin{array}{l}\text { Percaya akan } \\
\text { khasiat obat } \\
\text { tradisional }\end{array}$ & $\begin{array}{l}425 / \\
525\end{array}$ & 81,0 & $\begin{array}{c}\text { Sangat Setuju } \\
\text { atau Sangat } \\
\text { Baik }\end{array}$ \\
\hline $\begin{array}{l}\text { Obat } \\
\text { tradisional } \\
\text { dipercaya } \\
\text { secara turun- } \\
\text { temurun }\end{array}$ & $\begin{array}{l}434 / \\
525\end{array}$ & 82,7 & $\begin{array}{c}\text { Sangat Setuju } \\
\text { atau Sangat } \\
\text { Baik }\end{array}$ \\
\hline $\begin{array}{l}\text { Sediaaan obat } \\
\text { tradisional } \\
\text { menarik }\end{array}$ & $\begin{array}{l}366 / \\
525\end{array}$ & 69,7 & $\begin{array}{c}\text { Setuju atau } \\
\text { Baik }\end{array}$ \\
\hline
\end{tabular}

Bersadarkan data diatas persepsi yang banyak timbul pada masyarakat Kelurahan Simpang Baru Kecamatan Tampan Kota Pekanbaru mengenai obat tradisional adalah obat tradisional digunakan secara turun-temurun $82,7 \%$ dan diketahui sisanya yaitu $17,3 \%$ responden menolak pernyataan tersebut berasal dari usia dewasa awal. Usia dewasa awal belum memiliki banyak pengalaman dibandingkan dengan usia madya dan usia lanjut sehingga pengalaman sangat berpengaruh terhadap persepsi seseorang karena faktor persepsi juga berkaitan dengan pengalaman dan ingatan seseorang.

Pengalaman merupakan sumber pengetahuan atau suatu cara untuk memperoleh kebenaran dan pengetahuan (Mubarak, 2007) maka dari itu usia sangat berpengaruh karena lebih banyak memiliki pengalaman seperti pada usia madya dan usia lanjut akan mempunyai pengetahuan yang baik terhadap penggunaan obat tradisional.

Persepsi yang banyak timbul di masyarakat selanjutnya mengenai penggunaan obat tradisional adalah percaya akan khasiat obat tradisional. Dari penelitian ini dapat diketahui masih banyak masyarakat meyakini bahwa persepsi mereka mengenai khasiat obat tradisional yang lebih aman karena terbuat dari bahan alami dan apabila dikonsumsi dalam jangka waktu yang panjang tidak menimbulkan efek samping.

Hasil penelitian ini sejalan dengan yang dilakukan Hidayati dan Perwitasari pada tahun (2011) mengenai persepsi masyarakat terhadap obat tradisional di Umbulharjo Kota Yogyakarta bahwa masyarakat juga setuju dengan khasiat dari obat tradisional yang digunakan.

\section{SIMPULAN}

Berdasarkan penelitian yang telah dilakukan tentang persepsi masyarakat mengenai obat tradisional di Kelurahan Simpang Baru Kecamatan Tampan Kota Pekanbaru dapat disimpulkan bahwa persepsi yang banyak timbul dimasyarakat mengenai obat tradisional adalah obat tradisional buatan Indonesia kandungannya lebih aman (halal) $(87,8 \%)$ dan untuk persepsi terhadap alasan masyarakat menggunakan obat tradisional karena obat tradisional digunakan secara turun-temurun $(82,7 \%)$.

\section{DAFTAR PUSTAKA}

Alim, S. A., Mawardi, M. K., Bafadhal, A. S. 2018. Pengaruh Persepsi Label Halal dan Kualitas Produk Terhadap Keputusan Pembelian Produk Fesyen. Malang: Jurnal Administrasi Bisnis

Anonim. 2013. Lampiran Peraturan Menteri Kesehatan Republik Indonesia Nomor 88 Tahun 2013 Tentang Rencana Induk Pengembangan Bahan Baku Obat Tradisional. Jakarta: Depertemen Kesehatan RI

Anonim. 2017. Statistik Kantor Kelurahan Simpang Baru. Pekanbaru: Kantor Lurah Simpang Baru.

Anonim. 2018. Riset Kesehatan Dasar (RISKESDAS) 2018. Laporan Nasional 2013. Jakarta: Badan Penelitian dan Pengembangan Kesehatan.

Alamsyah. I. E. 2018. Obat Tradisional Terus MenjadiKebutuhan.https://www.republika.co.i $\mathrm{d} /$ berita/nasional/umum/18/11/01/phiqpc349bp om. Diakses 20 Juli 2019

Burhani. R. 2017. Fitofarmaka Terdaftar Badan Pengawas Obat dan Makanan Baru 18 Obat. http://www.antaranews.com/berita/663929/fito farmakaterdaftar-bpom baru-18-obat. Diakses 19 Juli 2019 
Bustanussalam. 2016. Pemanfaatan Obat Tradisional (Herbal) Sebagai Obat Alternatif. Biotrens.

Ervina. L., dan Ayubi, D. 2018. Peran Kepercayaan Terhadap Penggunaan Pengobatan Tradisional Pada Penderita Hipertensi Di Kota Bengkulu. Jurnal perilaku dan promosi kesehatan

Febtriko. A dan Puspitasari, I. 2018. Mengukur Kreatifitas dan Kualitas Pemograman Pada Siswa SMK Kota Pekanbaru Jurusan Teknik Komputer Jaringan dengan Simulasi Robot. Jurnal teknologi dan sistem informasi Universitas Abdurrab Pekanbaru

Hidayati. A., dan Perwitasari, D. A. 2011. Persepsi Pengunjung Apotek Menggenai Penggunaan Obat Bahan Alam Sebagai Alternatif pengobatan di kelurahan Muja Muju kecamatan Umbul Harjo Kota Yogyakarta. jurnal Prosiding Seminar Nasional "Home Care,".

Istaminingdyah. R. 2008. Dasar-Dasar Pertimbangan Upaya Pengobatan Sendiri Pada Masyarakat Di Kabupaten Klaten. Skripsi Fakultas Farmasi Universitas Ahmad Dahlan.

Jati, Y. W. 2008. Badan Pengawas Obat dan Makanan 54 Merek Jamu Dilarang Beredar. Bisnis Indonesia, Jakarta.

Novia. F. 2018. Gambaran Penggunaan Obat Tradisional sebagai Alternatif Pengobatan pada masyarakat di Kelurahan Simpang Baru Kecamatan Tampan Kota Pekanbaru, Karya Tulis Ilmiah. Pekanbaru: Sekolah Tinggi Ilmu Farmasi Riau

Merdekawati, R. 2016. Gambaran dan Tingkat Pengetahuan Penggunaan Obat Tradisional Sebagai Alternatif Pengobatan Pada Masyarakat RW 005 Desa Sindurjan, Kecamatan Purworejo. Naskah Publikasi Skripsi. Yokyakarta: Universitas Muhammadiyah. Yogyakarta.

Mubarak, W. I. 2007. Promosi Kesehatan Sebuah Pengamatan Proses Belajar Mengajar dalam Pendidikan. Yogyakarta: Graha Ilmu.

Rahayu, D. A. 2012. Faktor-Faktor yang Berhubungan Dengan Pemilihan Pengobatan Tradisional Di Wilayah Kerja Puskesmas Muara Siberut Kecamtan Siberut Selatan Kabupaten Kepulauan Mentawai. Jurnal Penelitian

Sumarwan, U. 2014. Perilaku Konsumen Teori dan Penerapannya Dalam Pemasaran. Jakarta: Ghalia Indonesia Swastha, Basu Irawan. 1990.

Walgito, B. 2010. Pengantar psikologi umum. Yogyakarta: penerbit Andi 